\title{
Taxonomic reassessment of the genus Chlorella (Trebouxiophyceae) using molecular signatures (barcodes), including description of seven new species
}

\author{
Christina Bock ${ }^{1,2}$, Lothar KRIENITZ ${ }^{*}$ and Thomas PRÖSCHOLD ${ }^{3,4}$ \\ ${ }^{1}$ Leibniz-Institute of Freshwater Ecology and Inland Fisheries, Alte Fischerhütte 2, \\ D-16775 Stechlin-Neuglobsow, Germany; *e-mal: krie@igb-berlin.de, tel.: 03308269926, \\ fax: 03308269917 \\ ${ }^{2}$ University of Essen, Faculty of Biology, D-45141 Essen, Germany \\ ${ }^{3}$ Culture Collection of Algae and Protozoa, Scottish Association for Marine Science, Dunstaffnage Marine \\ Laboratory, Dunbeg by Oban, Argyll, PA37 1QA, United Kingdom \\ ${ }^{4}$ University of Vienna, Dept. Limnology, Althanstr. 14, A-1090 Vienna, Austria
}

\begin{abstract}
After the description of Chlorella vulgaris by Beijerinck, 120 years ago, members of the genus Chlorella belong to the best studied green algae worldwide. However, numerous open questions remained regarding their systematics. Recent molecular studies showed the polyphyly of the genus within the Chlorophyceae and Trebouxiophyceae. Chlorella-species were traditionally characterized by spherical to oval cell shape, solitary lifeform and the absence of mucilaginous envelopes. The challenge in the past was how to distinguish species due to their high phylogenetic diversity combined with a limited amount of morphological characters. Using a polyphasic approach of SSU- and ITS rDNA phylogeny, secondary structure of the ITS and light microscopic observations, we were able to detect six lineages with Dictyosphaerium-like strains in close relationship to $C$. vulgaris, here described or combined newly as $C$. coloniales sp. nov., $C$. pituita sp. nov., $C$. pulchelloides sp. nov., C. singularis sp. nov., $C$. elongata comb. nov. and C. chlorelloides comb. nov. Furthermore, three new species without mucilage were described as $C$. lewinii sp. nov., C. rotunda sp. nov. and C. volutis sp. nov. Using the $5.8 \mathrm{~S}$ rRNA and part of the ITS-2 as molecular signature (barcode), we were able to distinguish not only the five already known species of Chlorella, C. vulgaris, C. sorokiniana, C. heliozoae, C. lobophora and C. variabilis but the seven new species and two new combinations as well. CBCs and hemi-CBCs within the secondary structure of the ITS-2 confirmed the separation of the species. Our study led to a new understanding of the evolution of morphology within the genus Chlorella and to an emendation of the generic description.
\end{abstract}

Key words: barcode, Chlorella, Dictyosphaerium, ITS, mucilage, phylogeny

\section{Introduction}

Chlorella BEIJERINCK is one of the most famous microalgal genera worldwide. Although members of the genus suffer from a scarcity of morphological characters, more than 100 Chlorella species have been named since the description of the type species Chlorella vulgaris BEIJERINCK in 1890. These taxa have been described from freshwater, marine, and edaphic habitats or as endosymbionts (KOMÁREK \& FotT 1983; Huss et al. 1989; Nishihara et al. 1998; Hoshina et al. 2005; Summerer et al. 2008; ŠKaloud 2009; KhaYbULlina et al. 2010; PRÖSCHOLD et al. 2011). Over time, numerous studies aimed at revising the systematics of this genus have been carried out. These studies have mainly focused on their nutritional requirements (Shrift \& Sproul 1963; Shihira \& Krauss 1965), morphological and structural features (FotT \& NovÁKovÁ 1969; ANDREYeVA 1975; NozAKI et al. 1995), serological cross-reactions (SANDERS et al. 1971), ultrastructural and chemical composition of the cell wall (AtKINSON et al. 1972; KAPAUN \& Reisser 1995; Němcová \& Kalina 2000), pyrenoid ultrastructures (IKEDA \& TAKEDA 1995; NĚMcová \& KaLINA 2000), biochemical and physiological characters (KESSLER 1976, 1982; 1984, KeSSLER \& Huss 1992) and molecular phylogenetic characteristics (Huss et al. 1989, 1999; Huss \& Sogin 1990; Krienitz et al. 2004; Eliaš \& Neustupa 2009; DarienKo et al. 2010). All these studies have shown that the genus 
is a heterogeneous assemblage of species and that there is an urgent need for a revision of the genus. On the basis of biochemical and molecular data, the genus presently consists of only of five "true" Chlorella species: Chlorella vulgaris, $C$. lobophora ANDREYEVA, C. sorokiniana SHIHIRA et Krauss, $C$. heliozoae Pröschold et DarienKo and C. variabilis Shinira et Krauss (Huss et al. 1999; KrIENITZ et al. 2004; PröSCHOLD et al. 2011).

The separation of the genera and species of Chlorophyta has traditionally been based on morphological and cytological characters (Pröschold \& Leliaert 2007). However, the hypothesis that similar morphology leads to a close phylogenetic relationship has often been proven to be inaccurate and misleading. Recent phylogenetic studies have demonstrated that the typical Chlorella morphology is shared with other lineages of the Trebouxiophyceae and Chlorophyceae (Huss et al. 1999; Neustupa et al. 2009; DARIENKo et al. 2010). For example, DARIENKo et al. (2010) have shown in their study three ellipsoid Chlorella-like species that form a monophyletic lineage within the Trebouxiophyceae. The species previously known as Chlorella saccharophila (KRÜGER) MigUla, $C$. ellipsoidea GeRneCK, and C. angusto-ellipsoidea N. Hanagata et M. Chimara have on the basis of their phylogenetic characteristics been placed in the genus Chloroidium Nadson.

Members of the genus Chlorella belong traditionally to the Chlorellaceae, which have been recently divided in two different clades, the Parachlorella-clade and the Chlorellaclade (Krienitz et al. 2004; Luo et al. 2010). Investigations focusing on the Dictyosphaeriummorphotype (colonial, with connecting strands between the cells and gelatinous envelope) showed an affiliation of this morphotype to the Chlorellaceae (KRIENITZ et al. 2010). Recent studies showed that Dictyosphaerium-like strains cluster independently in the Parachlorella-clade and in the Chlorella-clade of the Chlorellaceae, some taxa among members of the genus Chlorella (Bock et al. 2010; Krienitz et al. 2010; Luo et al. 2010).

The current challenge in the study of this genus is how to distinguish individual species in the light of the extremely high phylogenetic diversity of the Chorella like species combined with the limited number of morphological characters and small dimensions of vegetative cells that hampers suitable identification and discrimination of individual taxa (ETTL \& GäRTNER 1995; NeUSTUPA et al. 2009).

The barcode initiative attempts to resolve the problem of species delimitation by defining a short and highly variable DNA region as barcode for the species (HAJiBABAEI et al. 2007). For the green algae, discussions are still going on which part of the DNA is suitable for barcoding. Studies on diatoms have shown that the cox 1 region is short, variable and a useful marker for phylogenetic analyses in combination with other genes (Evans et al. 2007; Evans \& MANN 2009). However, MonIZ \& KaCZMARSKA (2009) suggested a different barcode for diatoms based on a segment starting with the 5.8S start codon and ending in the conserved motif of the Helix III of the ITS-2. The ITS-2 is a comparably fast evolving sequence, which has been widely used for phylogenetic analyses at the generic and species levels (ÁlvarEZ $\&$ Wendel 2003; Miao et al. 2008). In addition to the primary sequence, the secondary structure of the ITS- 2 based on complementary base changes (CBC) has often been taken into account when distinguishing between closely related species (MülLER et al. 2007). Studies have shown that one CBC in a conserved region of the Helix II or III of the ITS-2 is in most cases associated to an inability for sexual reproduction (COLEMAN 2007, 2009; MülLER et al. 2007).

In this paper we investigated the phylogeny and morphology of 20 different strains from the genus Chlorella and described seven new species and three new combinations. In addition, we applied the Barcoding concept after Moniz \& KACZMARSKA (2009) to 49 sequences of the genus Chlorella and compared the results with CBCs in the secondary structure of the ITS- 2 and the traditional species delineation.

\section{Materials and methods}

Algal cultures and morphology. Strains were obtained either from the Culture Collection of Algae and Protozoa (CCAP, UK), Culture Collection of Algae at the University of Göttingen (SAG, Germany), the Culture Collection of Algae at the University of Texas (UTEX, USA), Coimbra Collection of Algae (ACOI, Portugal) or isolates from field material and deposited at CCAP (Table 1). All strains were grown at $15{ }^{\circ} \mathrm{C}$ under a 14/10h light/dark regime in modified Bourrelly medium (KRIENITZ \& WIRTH 2006). The morphology was analysed according to KoMÁreK \& FotT (1983) and Komárek \& Perman (1978). The chloroplast 


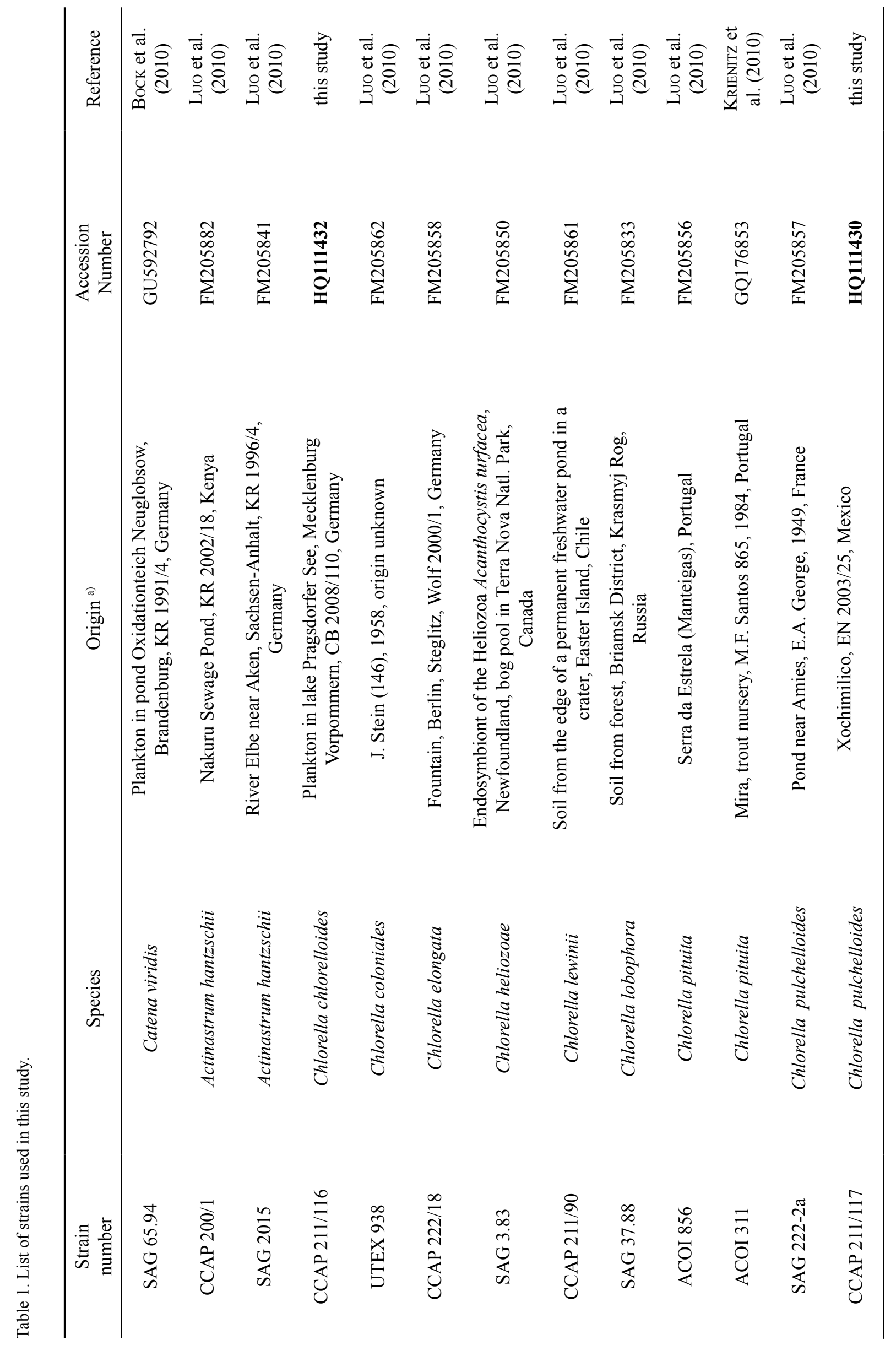




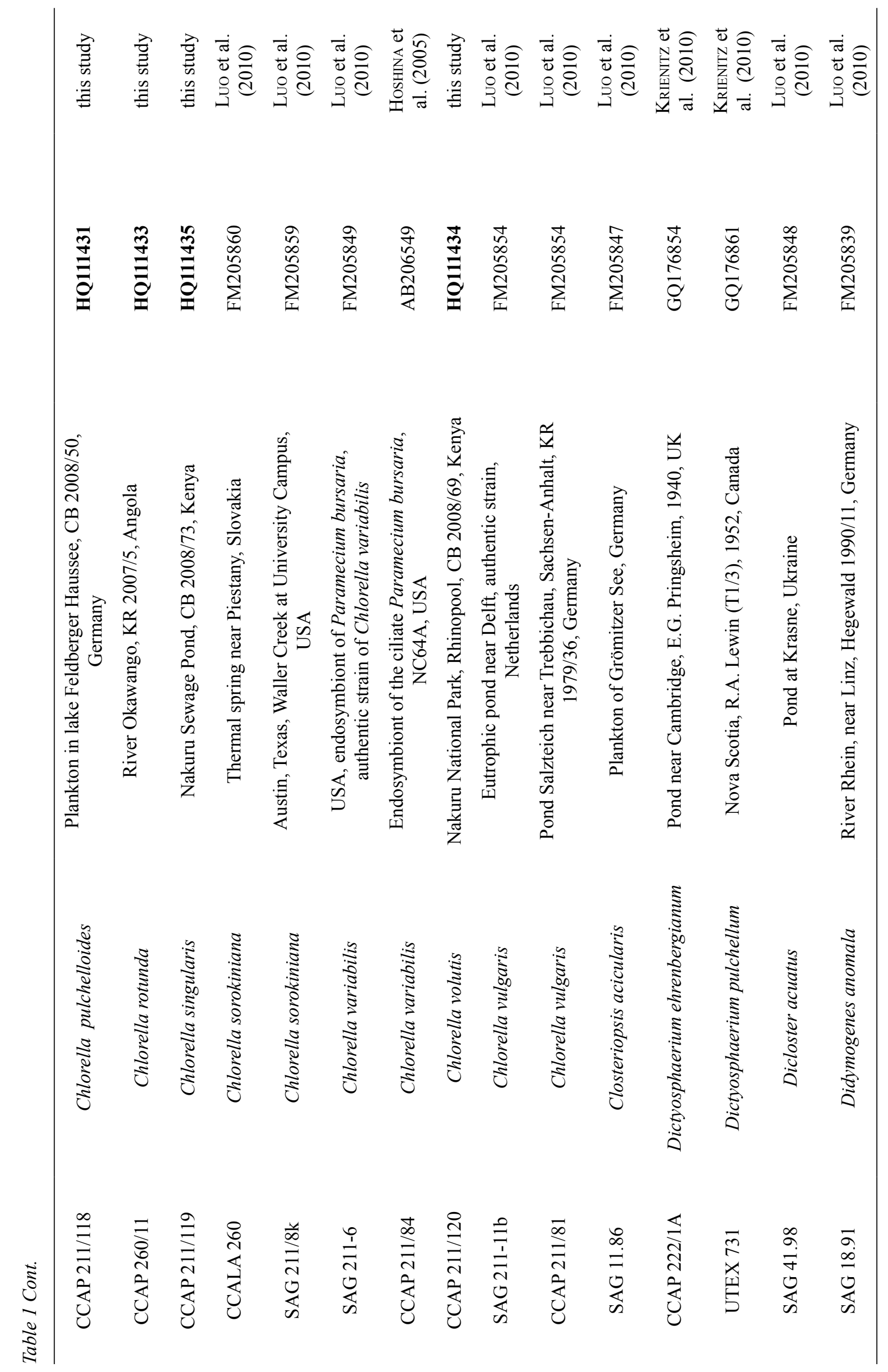




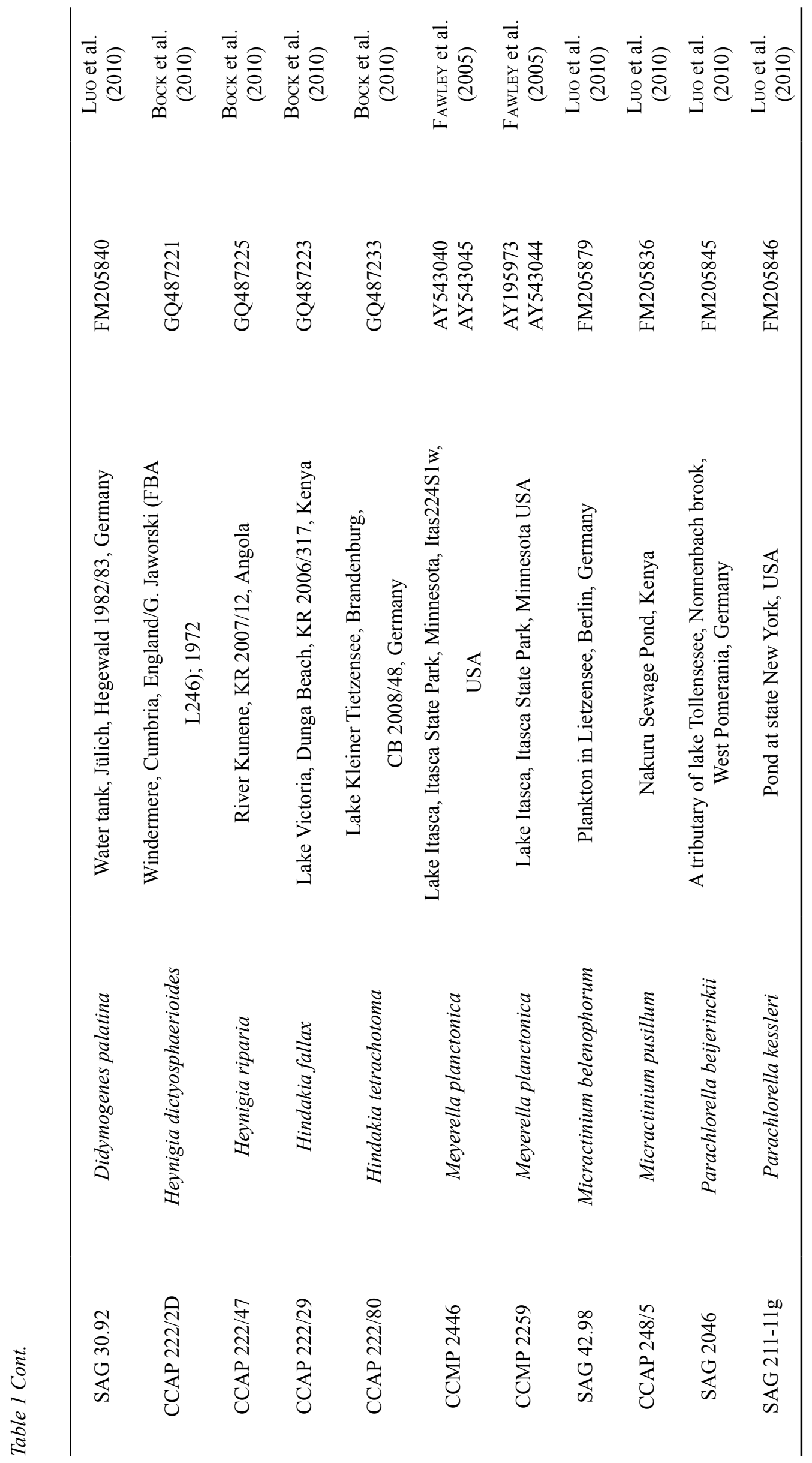


Table 2. Sequences used for $p$ calculation

\begin{tabular}{|c|c|c|}
\hline Species & $\begin{array}{l}\text { Accession } \\
\text { Number }\end{array}$ & Reference \\
\hline Chlorella chlorelloides & HQ111432 & this study \\
\hline Chlorella coloniales & FM205862 & Luo et al. (2010) \\
\hline Chlorella elongata & FM205858 & Luo et al. (2010) \\
\hline Chlorella heliozoae & FM205850 & Luo et al. (2010) \\
\hline Chlorella lewinii & FM205861 & this study \\
\hline Chlorella lobophora & FM205833 & Luo et al. (2010) \\
\hline Chlorella pituita & FM205856 & Luo et al. (2010) \\
\hline Chlorella pituita & GQ176853 & KRIENITZ et al. (2010) \\
\hline Chlorella pulchelloides & FM205857 & Luo et al. (2010) \\
\hline Chlorella pulchelloides & HQ111430 & this study \\
\hline Chlorella pulchelloides & HQ111431 & this study \\
\hline Chlorella rotunda & HQ111433 & this study \\
\hline Chlorella singularis & HQ111435 & this study \\
\hline Chlorella sorokiniana & FM205860 & Luo et al. (2010) \\
\hline Chlorella sorokiniana & FM205859 & Luo et al. (2010) \\
\hline Chlorella variabilis & AB162913 & HosHina et al. (2005) \\
\hline Chlorella variabilis & AB162912 & Hoshina et al. (2005) \\
\hline Chlorella variabilis & AB206546 & Hoshina et al. (2005) \\
\hline Chlorella variabilis & AB206550 & Hoshina et al. (2005) \\
\hline Chlorella variabilis & AB162914 & Hoshina et al. (2005) \\
\hline Chlorella variabilis & AB162915 & Hoshina et al. (2005) \\
\hline Chlorella variabilis & AB162916 & Hoshina et al. (2005) \\
\hline Chlorella variabilis & AB162917 & Hoshina et al. (2005) \\
\hline Chlorella variabilis & AB219527 & Hoshina et al. (2005) \\
\hline Chlorella variabilis & FM205849 & Luo et al. (2010) \\
\hline Chlorella variabilis & AB206549 & Hoshina et al. (2005) \\
\hline Chlorella volutis & HQ111434 & this study \\
\hline Chlorella vulgaris & AY591508 & MüLLER et al. (2005) \\
\hline Chlorella vulgaris & AB162910 & Hoshina et al. (2005) \\
\hline Chlorella vulgaris & AY591509 & MüLLER et al. (2005) \\
\hline Chlorella vulgaris & AY591510 & MÜLLER et al. (2005) \\
\hline Chlorella vulgaris & AY591511 & MÜLLER et al. (2005) \\
\hline Chlorella vulgaris & AY591512 & MÜLLER et al. (2005) \\
\hline Chlorella vulgaris & AY591513 & MÜLLER et al. (2005) \\
\hline Chlorella vulgaris & AY591500 & MÜLLER et al. (2005) \\
\hline Chlorella vulgaris & AY591501 & MüLLER et al. (2005) \\
\hline Chlorella vulgaris & AY591502 & MÜLLER et al. (2005) \\
\hline Chlorella vulgaris & AY591503 & MÜLLER et al. (2005) \\
\hline Chlorella vulgaris & AY591504 & MüLLER et al. (2005) \\
\hline Chlorella vulgaris & AY591505 & MÜLLER et al. (2005) \\
\hline Chlorella vulgaris & AY591506 & MÜLLER et al. (2005) \\
\hline Chlorella vulgaris & AY591493 & MÜLLER et al. (2005) \\
\hline Chlorella vulgaris & AY591494 & MÜLLER et al. (2005) \\
\hline Chlorella vulgaris & AY591495 & MÜLLER et al. (2005) \\
\hline Chlorella vulgaris & AY591496 & MÜLLER et al. (2005) \\
\hline Chlorella vulgaris & AY591497 & MÜLLER et al. (2005) \\
\hline Chlorella vulgaris & AY591498 & MÜLLER et al. (2005) \\
\hline Chlorella vulgaris & AY591499 & MüLLER et al. (2005) \\
\hline Chlorella vulgaris & FM205854 & Luo et al. (2010) \\
\hline
\end{tabular}


descriptions followed FoTT \& NovÁKovÁ (1969).

DNA isolation, PCR and sequencing. Algal cells were mechanically disrupted in the presence of glass beads ( $\sim 0.5 \mathrm{~mm}$ in diameter, Carl Roth $\mathrm{GmbH}+\mathrm{Co} . \mathrm{KG}$, Karlsruhe, Germany) using the Tissuelyser II (Qiagen). Total Genomic DNA was isolated using the DNeasy Plant Mini Kit (Qiagen GmbH, Hilden, Germany) following the instructions given by the manufacturer. Genomic DNA will be stored at the BGBM DNA Network (GEMEINHOLZER et al. 2008). The SSU and ITS rRNA gene were amplified and sequenced as previously reported (Bock et al. in press). The overlapping partial sequences of each strain were assembled to a complete consensus sequencing consisting of SSU, ITS-1, 5.8S, ITS-2 using the software SeqAssem (HEPPERLE 2004).

Phylogenetic analyses. Phylogenetic analyses were performed on a concatenated data set of SSU, 5.8S, ITS-1 and ITS-2 rRNA sequences. The alignement was constructed by adding sequences of the known Chlorella species (Luo et al. 2010; PröSCHOLD et al. 2011) to the newly obtained sequences. Representatives of the different genera of the Chlorella and Parachlorella clades were chosen according to Luo et al. (2010) and Bock et al. (2010). Catena viridis Chodat was chosen as outgroup based on previous analyses by KRIENITZ et al. (2003) and Bock et al. (2010). The sequences were aligned using the SequentiX Alignment Editor (HEPPERLE 2004) according to their secondary structure (see Figs S1 and S2 in Luo et al. 2006) and manually adjusted by eye. The GenBank accession numbers for all included strains are given in Table 1. A data set of 39 strains with 2488 aligned bases positions was used for the phylogenetic analyses, introns were excluded.

Phylogenetic inference was based on Maximum Likelihood (ML), Maximum Parsimony (MP), distance (Neighbor Joining; NJ) and Bayesian Inference (MB). MP and NJ were calculated using PAUP* (version 4.0b10; SwOFFord 2002). The ML analyses were perfomed with Treefinder (JoBB 2008) with four partitions. Models and parameters proposed by Treefinder under AICc criteria were as follows: SSU (1701 bases; model J1), ITS-1 (343 bases; model J1), 5.8S (137 bases; model HKY) and ITS-2 (304 bases; model J2). To confine the tree topology, bootstrap analyses were calculated by distance (NJ; 1000 replicates), parsimony (MP; 1000 replicates) and ML (1000 replicates) criteria. For the MB analyses, the dataset was partitioned as described above with the $\mathrm{GTR}+\mathrm{I}+\mathrm{G}$ settings, gamma shape parameters and proportion of invariable sits for all partitions using MrBayes version 3.1 (HuELSENBECK \& RoNQuisT 2001). The parameters were unlinked and allowed to vary across the partitions. The stationary distribution was verified (average standart deviations of split frequencies lower than 0.01 ) before stop of the analyses. The first $25 \%$ of the trees were discarded as burn-in.
A 50\% majority-rule consensus tree was calculated for posterior probabilities using PAUP*.

Barcode and secondary structure analyses. A dataset of 49 sequences of Chlorella-strains was used for analyzing the Barcode region (Table 2). The Barcoding region stretches from the start codon of the 5.8S rDNA up to the conserved motif on Helix III (consisting of UGGU) near the tip of the helix and close to the end of the ITS-2 (KRIENITZ et al. 2004; ColEmAn 2007). Sequences were aligned manually according to their secondary structure using SequentiX Alignment Editor (HePPERLE 2004). Completed alignments were imported into PAUP*(4.0b10; SwOFFord 2002) for estimating divergence rates by using simple uncorrected pairwise $(p)$ distance matrices. Genetic distances between sequences were given as substitutions (differences) per site (LITAKER et al. 2007).

To locate hemi-compensatory base changes (hemi-CBCs) and CBCs, the ITS-2 secondary structure was constructed with the help of mfold (ZUKER 2003) and 4SALE (SEIBEL et al. 2006, 2008).

\section{Results}

\section{Taxonomic revision}

The taxonomic revisions (see below) were based on the results such as morphology, the phylogenetic tree, secondary structure of the ITS-2 and the barcoding criteria. The new species and new combinations showed base changes at the barcoding-region mentioned below.

\section{Chlorella BEIJERINCK 1890}

BEIJERINCK, M.W. 1890, Botanische Zeitung 48: p. 758, tafel VII, fig. 2

Emended Diagnosis: Class Trebouxiophyceae; cells spherical, subspherical or ellipsoid, single or forming colonies with up to 64 cells, mucilage present or absent. Chloroplast single, parietal, pyrenoid present, surrounded by starch grains. Reproduction by autospores, zoospores lacking. Autospores released through disruption of mother cell wall. Daughter cell can remain attached to remnants of mother cell wall and form colonies with mucilage envelopes. Planktonic, edaphic or endosymbiontic.

Type species: Chlorella vulgaris BEIJERINCK

\section{Chlorella pituita C. Bock, KrIENITZ et Pröschold, sp. nov. (Figs 1, 8, 9)}

Latin diagnosis: Cellulae in coloniis vel solitariae, planctonicae. Coloniae 4-32 cellularis, 40-50 $\mu \mathrm{m}$ in diametro, cum tegumento mucilagineis vestitae. 


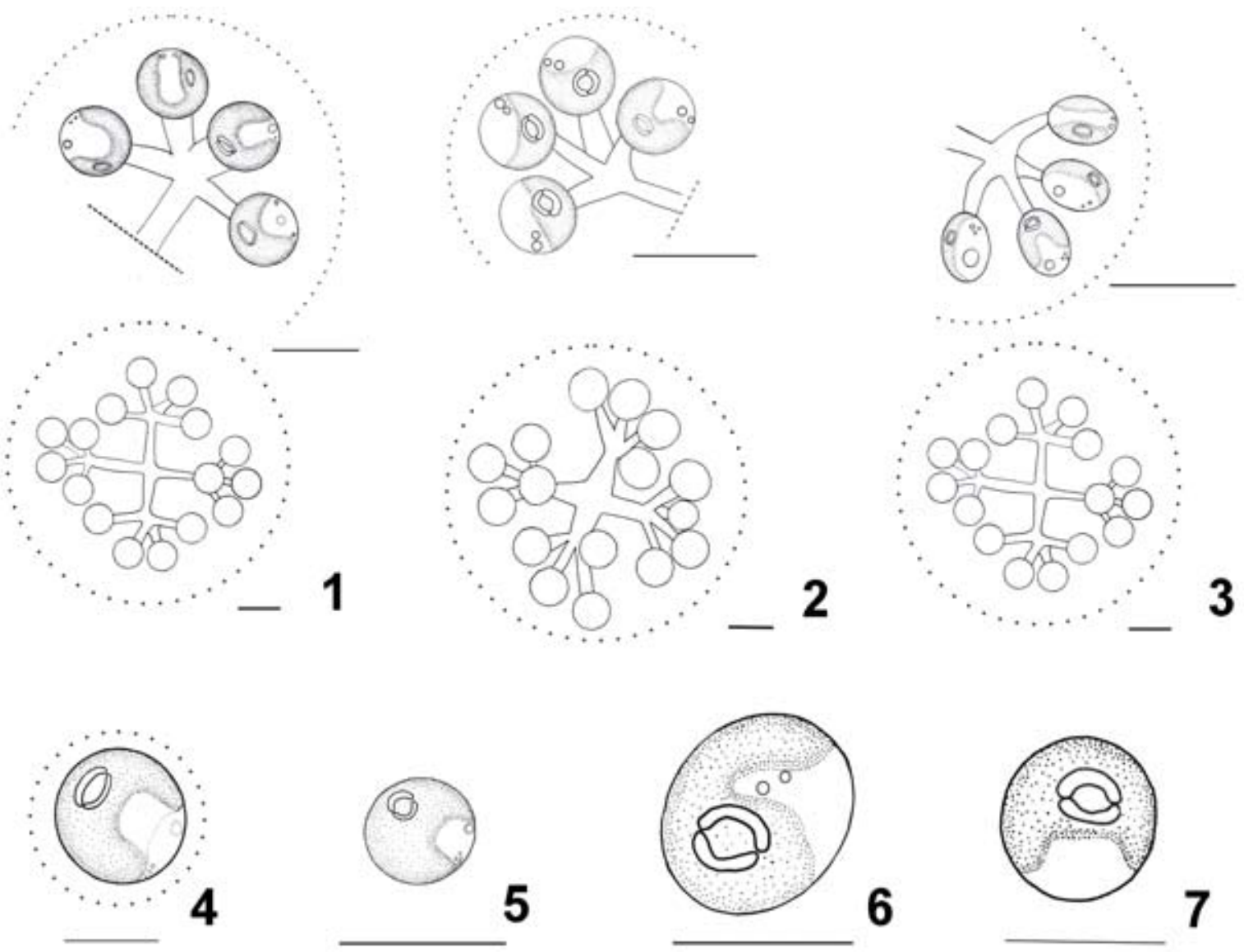

Figs 1-7. Drawings of light microscopical characters of Chlorella species. Iconotypes: (1) Chlorella pituita, authentic strain ACOI 311; (2) Chlorella pulchelloides, authentic strain CCAP 211/118; (3) Chlorella coloniales, authentic strain UTEX 938; (4) Chlorella singularis, authentic strain CCAP 211/119; (5) Chlorella rotunda, authentic strain CCAP 260/11; (6) Chlorella lewinii, authentic strain CCAP 211/90; (7) Chlorella volutis, authentic strain CCAP 211/120. Scale bars $10 \mu \mathrm{m}$.

Cellulae adultae rotundae vel leviter ovalis, 6.5-8.6 × 5.5-8 $\mathrm{\mu m}$, cellulis funibus subtilibus hyalinis iunctis . Cellulae juvenilis ovalis vel prope sphericae, 6-8 × 4.3-5.3 $\mathrm{m}$, funibus junctus ad apices latiusculis. Chloroplastus unicus, parietalis, poculiformis patelliformisve, pyrenoide granis amylis tecto. Reproductio asexualis 2-4 autosporum ope, e ruptura cellulis matricalis oblique vel horizontaliter. A speciebus ceteris generis ordine nucleotidorum in ITS-1, ITS-2 et signis molecularis differt.

Cells colonial or single, planktonic. Colonies 4-32 celled, with mucilaginous envelope. Diameter of colonies up to $40-50 \mu \mathrm{m}$. Adult cells spherical to slightly oval, $6.5-8.6 \times 5.5-8 \mu \mathrm{m}$, connected via mucilaginous stalks. Young cells oval to almost spherical, 6-8 $\times$ 4.3-5.3 $\mu \mathrm{m}$, connected to the stalks more or less at the apices of the broader side. Chloroplast single, parietal, cup- or saucershaped with ellipsoid to spherical pyrenoid, covered by two starch grains. Reproduction by 2-4 autospores. Release of the autospores obliquely or horizontally. Differs from other species of this genus by the order of nucleotides in ITS-1, ITS-2 and the barcoding signatures.

Holotype: An air-dried as well as a formaldehydefixed sample of strain ACOI 311 was deposited at the Botanical Museum at Berlin-Dahlem under the designation B40 0040661

Type locality: Mira, trout nursery, Portugal. Ethymology: from Latin: pituita = mucilage Authentic strain: Material of the authentic strain ACOI 311 is maintained at the Coimbra Collection of Algae, Portugal.

Iconotype: Figure 1

\section{Chlorella pulchelloides C. Bock, KRIENITz et} Pröschold, sp. nov. (Figs 2, 10, 11)

Latin diagnosis: Cellulae in coloniis, planctonicae, interdum tegumento gelatinoso vestitae. Coloniae 4-32 cellularis, 25-35 $\mathrm{\mu m}$ in diametro. Cellulae adultae sphaericae, 4.5-6.5 $\mu \mathrm{m}$ diametro, cellulis funibus subtilibus hyalinis iunctis. Cellulae juvenilis ovalis vel ovoides, 3.5-4.5 × 4-6 $\mu \mathrm{m}$, funibus 


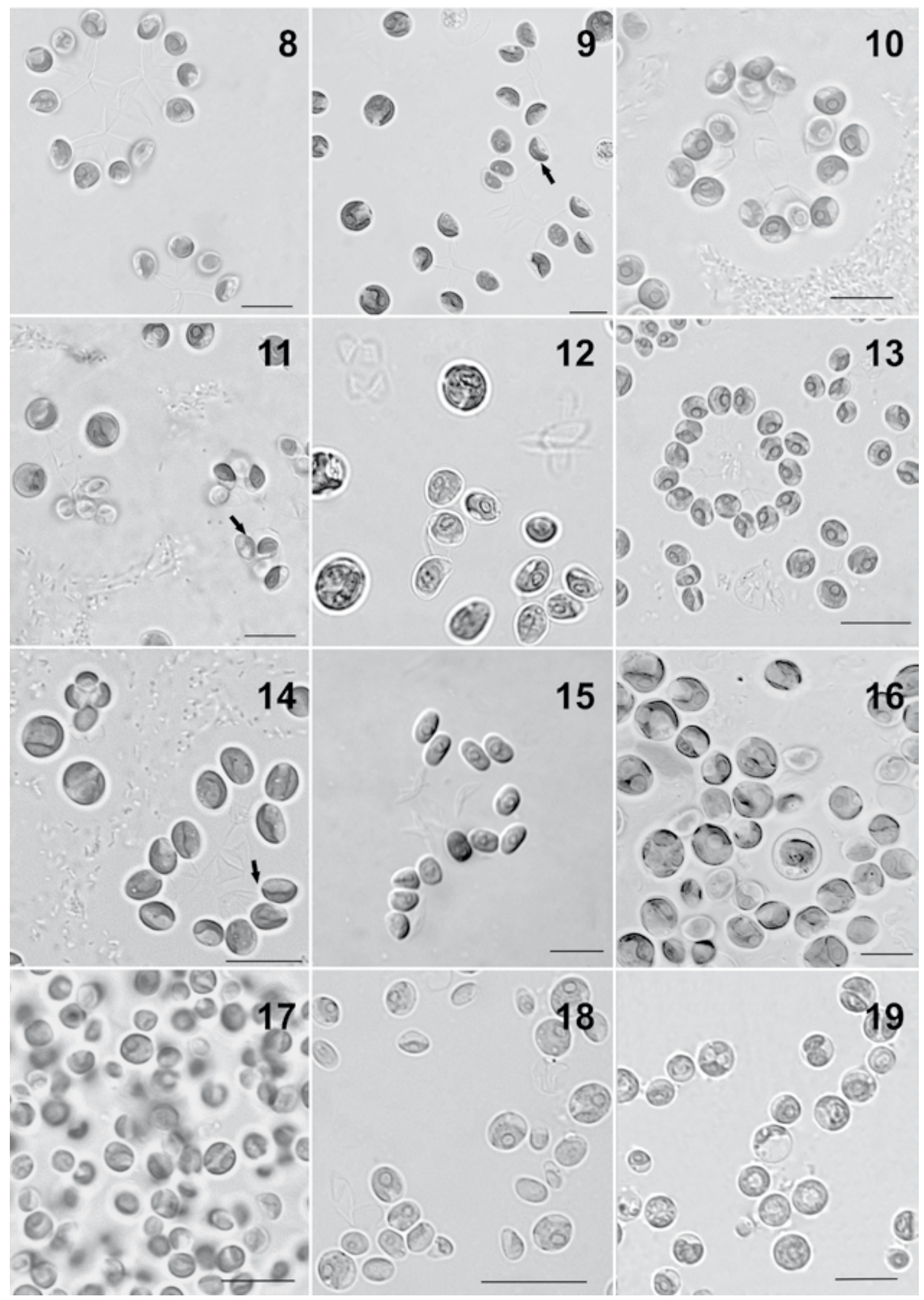

Figs 8-19. Micrographs of different Chlorella strains: (8-9) Chlorella pituita (ACOI 311); (10-11) Chlorella pulchelloides (CCAP 211/117); (12) Chlorella chlorelloides (CCAP 211/116); (13-14) Chlorella coloniales (UTEX 938) ; (15) Chlorella elongata (CCAP 222/18); (16) Chlorella singularis (CCAP 211/119); (17) Chlorella rotunda (CCAP 260/11); (18) Chlorella lewinii (CCAP 211/90); (19) Chlorella volutis (CCAP 211/120). Scale bars $10 \mu \mathrm{m}$. Arrowheads indicating connection of cells to mucilagenous stalks. 
junctus ad apices latiusculis. Chloroplastus unicus, parietalis, poculiformis, pyrenoide granis amylis tecto. Reproductio asexualis 2-4 autosporum ope, e ruptura cellulis matricalis oblique vel horizontaliter. A speciebus ceteris generis ordine nucleotidorum in ITS-1,ITS-2 et signis molecularis differt.

Cells colonial, planktonic, with mucilaginous envelope. Colonies 4-32 celled, diameter of colonies 25-35 $\mu \mathrm{m}$. Adult cells spherical 4.5-6.5 $\mu \mathrm{m}$, connected via mucilaginous stalks. Young cell oval to ovoid, 3.5-4.5 × 4-6 $\mu \mathrm{m}$, attached to the stalks at their broader side. Chloroplast single, parietal, cup- or saucer-shaped with ellipsoid to spherical pyrenoid, covered by two starch grains. Reproduction by 2-4 autospores. Release of autospores after rupture of mother cell wall horizontally or slightly obliquely. Differs from other species of this genus by the order of nucleotides in ITS-1 and ITS-2 and the barcoding signatures.

Holotype: Material of the authentic strain CCAP 211/118 is cryopreserved at the Culture Collection of Algae and Protozoa, Oban, Scotland.

Isotype: An air-dried as well as a formaldehydefixed sample of strain CCAP211/118 was deposited at the Botanical Museum at Berlin-Dahlem under the designation B40 0040664

Type locality: Lake Feldberger Haussee, Brandenburg, Germany (53'20'27,35'N; 1326'10,89'”E).

Ethymology: from Latin: pulchella $=$ nice

Authentic strain: CCAP 211/118

Iconotype: Figure 2

\section{Chlorella colonialis C. BoCK, KRIENITZ et Pröschold, sp. nov. (Figs 3, 13, 14)}

Latin diagnosis: Cellulae in coloniis, planctonicae, interdum tegumento gelatinoso vestitae. Coloniae 4-32 cellularis, 25-35 $\mathrm{mm}$ in diametro. Cellulae adultae late ellipsoidae, ovalis ad elongates 5.5-7.5 $\times$ 4-5 $\mu \mathrm{m}$, cellulis funibus subtilibus hyalinis iunctis. Cellulae juvenilis ovalis vel ovoides, 3-4.5 × 2.5-3.5 $\mu \mathrm{m}$ Chloroplastus unicus, parietalis, poculiformis, pyrenoide granis amylis tecto. Reproductio asexualis autosporum ope. A speciebus ceteris generis ordine nucleotidorum in ITS-1, ITS-2 et signis molecularis differt.

Cells colonial, planktonic, with mucilagenous envelope. Colonies 4-32 celled, diameter of colonies 25-35 $\mu \mathrm{m}$. Adult cells broadly ellipsoid, oval to elongate, 5.5-7.5 × 4-5 $\mu \mathrm{m}$, connected via mucilaginous stalks at narrow ends. Young cells oval to ovoid, $3-4.5 \times 2.5-3.5 \mu \mathrm{m}$. Chloroplast single, parietal, cup-or saucer-shaped with ellipsoid to spherical pyrenoid, covered by two starch grains. Reproduction by autospores. Differs from other species of this genus by the order of nucleotides in ITS-1 and ITS-2 and the barcoding signatures.

Holotype: An air-dried as well as a formaldehydefixed sample of the authentic strain UTEX 938 was deposited at the Botanical Museum at BerlinDahlem under the designation B40 0040665

Type locality: type locality unknown, studied culture UTEX 938 isolated in 1958 from J. Stein Ethymology: from Latin: colonialis = colonial Authentic strain: Material of the authentic strain UTEX 938 maintained at the Culture Collection of Algae at the University of Texas, USA.

Iconotype: Figure 3

\section{Chlorella singularis C. BoCK, KRIENITZ et Pröschold, sp. nov. (Figs 4, 16)}

Latin diagnosis: Cellulae solitariae, planctonicae. Cellulae adulate globose vel leviter ovalis, 6.7-9 $\mu \mathrm{m}$, interdum tegumento gelatinoso vestitae. Cellulae juvenilis ovalis vel globosae, 5-7 $\mu \mathrm{m}$. Chloroplastus unicus, parietalis, poculiformis, pyrenoide granis amylis tecto. Reproductio asexualis autosporum ope, e ruptura cellulis matricalis in 4 partibus. A speciebus ceteris generis ordine nucleotidorum in ITS-1, ITS-2 et signis molecularis differt.

Cells solitary, planktonic. Adult cells globose or slightly oval, 6.7-9 $\mu \mathrm{m}$, with mucilaginous envelope. Young cells oval to spherical, 5-7 $\mu \mathrm{m}$. Reproduction by autospores. Release of autospores after ruptures of mother cell wall into four flaps. Chloroplast parietal, cup- or saucer-shaped with ellipsoid to spherical pyrenoid, covered by two starch grains. Differs from other species of this genus by the order of nucleotides in ITS- 1 and ITS-2 and the barcoding signatures.

Holotype: Material of the authentic strain CCAP 211/119 is cryopreserved at the Culture Collection of Algae and Protozoa, Oban, Scotland.

Isotype: An air-dried as well as a formaldehydefixed sample of strain CCAP211/119 was deposited at the Botanical Museum at Berlin-Dahlem under the designation B40 0040666.

Type locality: Sewage pond, Nakuru-National Park, Nakuru District, Rift Valley Province, Kenya (0¹9'18,42'"S; 3604'38'E).

Ethymology: from Latin: singularis = single Authentic strain: CCAP 211/119 
Table 3. Light microscopical characters of the newly described Chlorella species [(M) mucilage].

\begin{tabular}{|c|c|c|c|c|c|c|c|}
\hline $\begin{array}{l}\text { Chlorella } \\
\text { species }\end{array}$ & $\begin{array}{c}\text { Adult cell } \\
\text { (young cell) } \\
\text { shape }\end{array}$ & $\begin{array}{l}\text { Adult cell } \\
\text { (young cell) } \\
\text { size } \\
(\mu \mathrm{m})\end{array}$ & $\begin{array}{l}\text { No. of } \\
\text { cells in } \\
\text { colony }\end{array}$ & $\begin{array}{l}\text { Colony } \\
\text { size } \\
(\mu \mathrm{m})\end{array}$ & $\begin{array}{l}\text { Connection } \\
\text { of young } \\
\text { cells to } \\
\text { gelatinous } \\
\text { stalks }\end{array}$ & M & $\begin{array}{l}\text { Release of } \\
\text { autospores }\end{array}$ \\
\hline C. pituita & $\begin{array}{l}\text { spherical to } \\
\text { slightly oval, } \\
\text { (oval to almost } \\
\text { spherical) }\end{array}$ & $\begin{array}{c}6.5-8.6 \times \\
5.5-8 \\
(6-8 \times \\
4.3-5.3)\end{array}$ & $4-32$ & $40-50$ & $\begin{array}{l}\text { at the apices } \\
\text { of the } \\
\text { broader side } \\
\text { of the cells }\end{array}$ & + & $\begin{array}{l}\text { oblique or } \\
\text { horizontal }\end{array}$ \\
\hline C. pulchelloides & $\begin{array}{l}\text { spherical (oval } \\
\text { to ovoid) }\end{array}$ & $\begin{array}{c}4.5-6-5 \\
(3.5-4.5 \times \\
4-6)\end{array}$ & $4-32$ & $25-35$ & $\begin{array}{l}\text { at the } \\
\text { broader side }\end{array}$ & + & $\begin{array}{c}\text { horizontal } \\
\text { or slightly } \\
\text { oblique }\end{array}$ \\
\hline C. colonialis & $\begin{array}{l}\text { broadly } \\
\text { ellipsoid, oval } \\
\text { to elongate }\end{array}$ & $\begin{array}{c}5.5-7.5 \times \\
4-5(3-4.5 \\
\times 2.5-3.5)\end{array}$ & $4-32$ & $25-35$ & $\begin{array}{l}\text { at narrow } \\
\text { ends }\end{array}$ & + & $\begin{array}{l}\text { oblique or } \\
\text { horizontal }\end{array}$ \\
\hline C. singularis & $\begin{array}{l}\text { globose or } \\
\text { slightly oval } \\
\text { (oval to } \\
\text { spherical) }\end{array}$ & $\begin{array}{l}6.7-9 \\
(5-7)\end{array}$ & 1 & - & - & + & $\begin{array}{c}\text { rupture of } \\
\text { cell wall }\end{array}$ \\
\hline C. rotunda & $\begin{array}{c}\text { globose, egg } \\
\text { shaped }\end{array}$ & $3.3-4.5$ & 1 & - & - & - & $\begin{array}{l}\text { rupture of } \\
\text { cell wall }\end{array}$ \\
\hline C. lewinii & $\begin{array}{c}\text { oval, egg } \\
\text { shaped }\end{array}$ & $4-6$ & 1 & - & - & - & $\begin{array}{l}\text { rupture of } \\
\text { cell wall }\end{array}$ \\
\hline C. volutis & globose & $5-6.5$ & 1 & - & - & - & $\begin{array}{l}\text { rupture of } \\
\text { cell wall }\end{array}$ \\
\hline
\end{tabular}

\section{Iconotype: Figure 4}

\section{Chlorella rotunda C. Bock, KRIENITZ et Pröschold, sp. nov. (Figs 5, 17)}

Latain Diagnosis: Cellulae solitariae planctonicae, globose vel ovoideae, 3.3-4.5 um diametro. Sine tegumento gelatinoso. Chloroplastus unicus, parietalis, olliformis patelliformisve, pyrenoide granis amylis tecto. Reproductio asexualis autosporum ope. A speciebus ceteris generis ordine nucleotidorum in ITS-1, ITS-2 et signis molecularis differt.

Cells solitary, planktonic, globose or egg shaped, 3.3-4.5 $\mu \mathrm{m}$. Mucilage absent. Chloroplast single, parietal, cup-, girdle- or saucer-shaped, with broadly ellipsoidal to spherical pyrenoid. Reproduction by autospores. Differs from other species of this genus by the order of nucleotides in ITS-1, ITS-2 and the barcoding signatures. Holotype: Material of the authentic strain CCAP
260/11 is cryopreserved at the Culture Collection of Algae and Protozoa, Oban, Scotland under the designation CCAP 260/11.

Isotype: An air-dried as well as a formaldehydefixed sample of strain CCAP 260/11 was deposited at the Botanical Museum at Berlin-Dahlem under the designation B40 0040662.

Type locality: Okawango, Angola.

Ethymology: from Latin: rotunda $=$ spherical

Authentic strain: CCAP 260/11

Iconotype: Figure 5

\section{Chlorella lewinii C. Bock, KRIENITz et} Pröschold, sp. nov. (Figs 6, 18)

Latin diagnosis: Cellulae solitariae edaphicae, ellipsoidae vel ovoideae, 4-6 $\mu \mathrm{m}$. Sine tegumento gelatinoso. Chloroplastus unicus, parietalis, olliformis patelliformisve, pyrenoide granis amylis tecto. Reproductio asexualis autosporum ope. A speciebus ceteris generis ordine nucleotidorum in ITS-1, ITS-2 et signis molecularis differt. 
Cells solitary, edaphic, oval or egg shaped, 4-6 $\mu \mathrm{m}$. Mucilage absent. Chloroplast single, parietal, cup-, girdle- or saucer-shaped, with broadly ellipsoidal to spherical pyrenoid. Reproduction by autospores, zoospores not observed. Differs from other species of this genus by the order of nucleotides in ITS-1, ITS-2 and the barcoding signatures.

Holotype: Material of the authentic strain CCAP 211/90 is cryopreserved at the Culture Collection of Algae and Protozoa, Oban, Scotland.

Isotype: An air-dried as well as a formaldehydefixed sample of strain CCAP 211/90 was deposited at the Botanical Museum at Berlin-Dahlem under the designation B40 0040663

Type locality: Permanent freshwater pond in a crater, Easter Island, Chile

Ethymology: The species is named in memory of the late Ralph Lewin, who was a leading authority in green algae genetics and who collected the original soil sample from the Easter Islands, from which the strain was isolated.

Authentic strain: CCAP 211/90

Iconotype: Figure 6

\section{Chlorella volutis C. Bock, KRIENITZ et}

Pröschold, sp. nov. (Figs 7, 19)

Latin diagnosis: Cellulae solitariae, planctonicae vel edaphicae, globose, 5-6.5 $\mu \mathrm{m}$. Chloroplastus unicus, parietalis. Sine tegumento gelatinoso. Chloroplastus unicus, parietalis, poculiformis, pyrenoide granis amylis tecto. Reproductio asexualis autosporum ope. A speciebus ceteris generis ordine nucleotidorum in ITS-1, ITS-2 et signis molecularis differt.

Cells solitary, planktonic or edaphic, globose, 5-6.5 $\mu \mathrm{m}$, without mucilaginous envelope. Chloroplast parietal, cup- or saucer-shaped with ellipsoid to spherical pyrenoid, covered by two starch grains. Reproduction by autospores, zoospores not observed. Differs from other species of this genus by the order of nucleotides in ITS -1 and ITS-2 and the barcoding signatures.

Holotype: Material of the authentic strain CCAP $211 / 120$ is cryopreserved in metabolic inactive state at the Culture Collection of Algae and Protozoa, Oban, Scotland.

Isotype: An air-dried as well as a formaldehydefixed sample of strain CCAP211/120 was deposited at the Botanical Museum at Berlin-Dahlem under the designation B40 0040733.

Type locality: Rhinopool Nakuru-National Park, small seasoning pond near the western border of the park, Nakuru District, Rift Valley Province,
Kenya $\left(00^{\circ} 23.421^{\prime} \mathrm{S}, 36^{\circ} 53.831 \mathrm{E}\right)$.

Ethymology: from Latin: volutis = rolling

Authentic strain: CCAP 211/120

Iconotype: Figure 7

\section{Chlorella chlorelloides (Naumann) C. Bock, Krienitz et Pröschold, comb. nov.}

Basionym: Brachionococcus chlorelloides NAUm., Ark. Bot. 16,2:15, 1919

Synonym: Dictyosphaerium chlorelloides (NAUm.) Komárek et Perman Algol. Stud. 20, p. no. 252, 1978.

Holotype: Fig. 8-9, Naumann 1921.

Epitype (designated here): Material of the strain CB2008/110 was cryopreserved in metabolic inactive state at the Culture Collection of Algae and Protozoa, Oban, Scotland under the designation CCAP 211/116.

Emended diagnosis: Cells solitary or in four celled colonies, sourrounded by mucilagenous envelope. Adult cells spherical 3.8-8 $\mu \mathrm{m}$, connected via mucilagenous stalks. Young cells oval to semilunate, $3-7 \times 2-6 \mu \mathrm{m}$, connected to the stalks with their narrow end. Chloroplast parietal, cup- or saucer-shaped with ellipsoid to spherical pyrenoid, covered by two starch grains. Reproduction by 2-4 autospores. Release of the autospores after rupture of mother cell wall by slanting in $180^{\circ}$.

\section{Chlorella elongata (Hindák) C. Bock, KRIENITZ et Pröschold, comb. nov.}

Basionym: Dictyosphaerium elongatum HINDÁK Biol. Práce 23:38, 1977

Synonym: Selenodictyon elongatum (HiNDÁK) ComAS et КомÁré in Comas 1992, Algol. Stud. 65: p. 22.

Epitype (designated here): Material of the strain CCAP 222/18 was cryopreserved at the Culture Collection of Algae and Protozoa, Oban, Scotland.

\section{Morphological observations by light micro- scope}

Within the newly analysed strains, seven species were observed with a surrounding mucilaginous envelope. The colonial life-form was often lost in culture, disintegrating into single cells. However, even in culture the strains kept their gelatinous indusium. C. pituita occurred in colonies with 16 cells and more. The adult cells were spherical to slightly oval, $6.5-8.6 \mu \mathrm{m}$. The young cells showed a oval cell shape, $6-8 \times 4-5 \mu \mathrm{m}$. The release of 


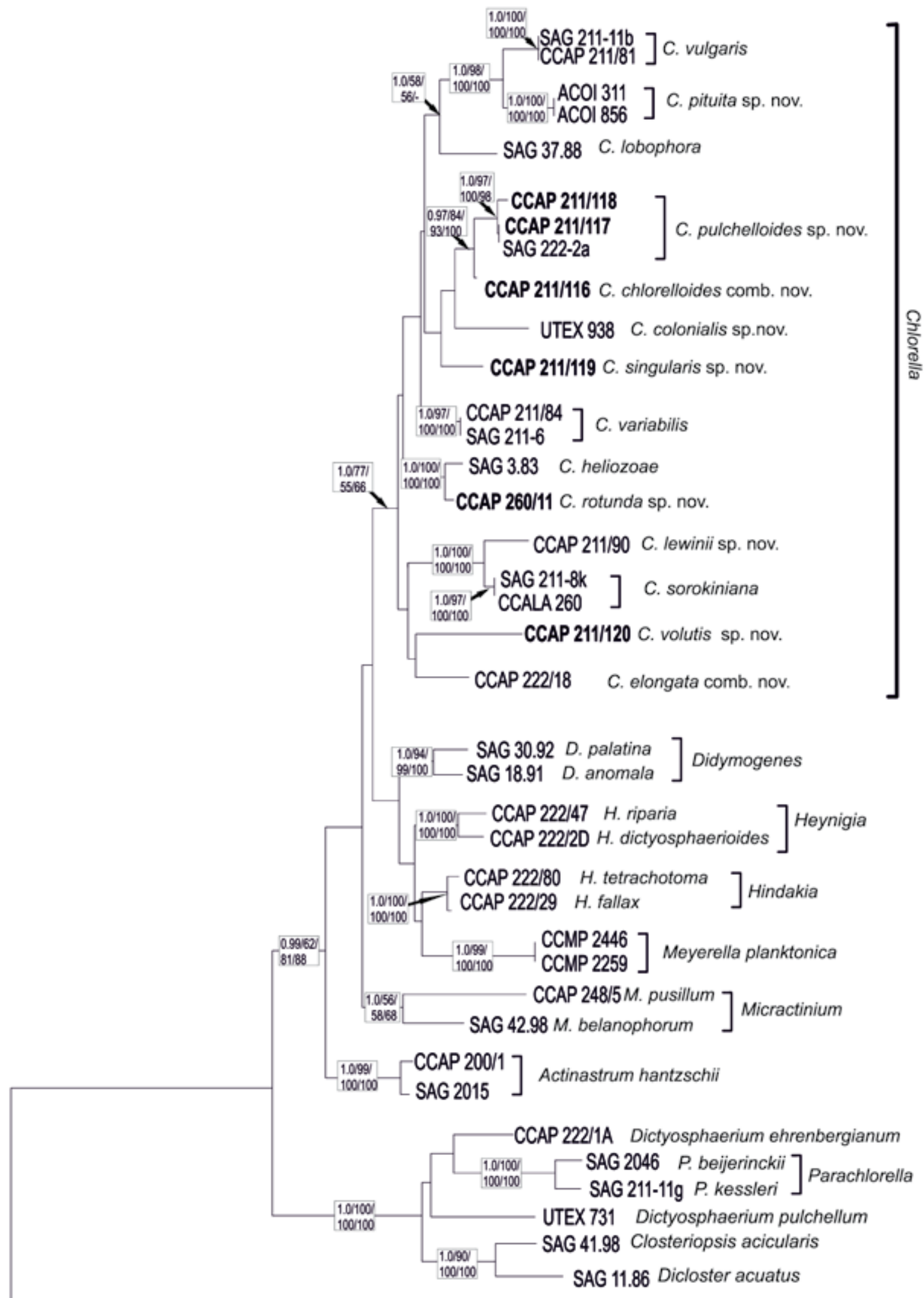

SAG 65.94 Catena viridis

0.1 substitutions/site

Fig. 20. Maximum likelihood (ML) phylogenetic tree of the Chlorellaceae as inferred from concatenated rRNA gene sequence data set of SSU, ITS-1, 5.8S and ITS-2 . Support values correspond to Bayesian PP, Maximum Likelihood BP, Maximum Parsimony BP and Neighbor Joining BP. Hyphen correspond to values lower than 50\% for BP and lower 0.95 for PP. Branch lengths represent substitutions per site. 
the autospores happened after the rupture of the mother cell wall horizontally or slightly tilted. The young cells were attached to the gelatinous stalks at their narrow end, but shifted to the upper end of their broader side (Figs 8-9). A similar morphology was observed by $C$. pulchelloides. However, the cells were smaller, $4.5-6.5 \mu \mathrm{m}$, in comparison to $C$. pituita and the oval young cells were attached at the broader side to the gelantinous stalks (Figs 10-11). Both species showed a high resemblance to Dictyosphaerium pulchellum. A clear morphological criterion to distinguish them is the attachment of the young cells to the stalks, which occurred in case of $D$. pulchellum at the tips of the cells. Strain CCAP 211/116 showed the typical features of $D$. chlorelloides with four-celled colonies (Fig. 12). The cells easily separated from each other. The adult cells were spherical, young cells oval to semilunate. The cell size of the adult cells were larger than previously reported; $6.5-8 \mu \mathrm{m}$ in our culture $v s .3 .8-6$ (7.5) $\mu \mathrm{m}$ according to KomÁreK \& Perman (1978). The autospores slanted after the rupture of the mother cell wall in $180^{\circ}$.

The cells of $C$. coloniales were oval to sometimes elongated, 5.5-7.3 $\times 4-6 \mu \mathrm{m}$. They occurred in colonies with 16 to 32 cells. The young cells were oval to ovoid, $3-4.5 \times 2.5-3.5$ um. The cells were attached to the stalks at their narrow end (Figs 13-14). This species showed a resemblance with strain CCAP 222/18 (Fig. 15). This strain showed oval or elongated adult cells of $6-9 \times 2-4 \mu \mathrm{m}$ length. The cells were attached to the stalks at their broader side. This strain could be identified as Dicytyosphaerium elongatum, and is here new combined to Chlorella elongata comb. nov. It can be distinuished from $C$. coloniales by the different cell form and the cell size. Chlorella singularis showed spherical to sligtly oval cells with 6.7-9 $\mu \mathrm{m}$ (Fig. 16). The mother cell wall ruptured in four flaps. This species was mainly observed single celled, only young cells occurred rarely as 4-celled colonies. The species showed similarities to Parachlorella beijerinckii, but differed by more spherical cells, the four-celled colonies and the phylogenetic position within the tree of our analyses (see below). Three new species without mucilage and without colony life-form could be observed in this study. Chlorella lewinii is an edaphic species that lacked a mucilage coat, did not form colonies and possessed spherical to slightly oval cells of 4-6 $\mu \mathrm{m}$ (Fig. 18). Young cells were more oval, $3-5 \times 2-5 \mu \mathrm{m}$. C. rotunda could be distinguished from $C$. lewinii by its much smaller cell size $(3-4.5 \mu \mathrm{m})$ and the more spherical cells (Fig. 17). Another single celled taxon without a mucilage envelope was Chlorella volutis. This species showed spherical cells of 5-6.3 $\mu \mathrm{m}$ with spherical to slightly oval young cells (Fig. 19). The morphological characteristics of the new described species are summarized in Table 3.

\section{Phylogenetic analyses}

The genus Chlorella is highly supported in Bayesian inference (MB), but only moderate to weak supported in Maximum Likelihood (ML), Neighbour Joining (NJ) and Maximum Parsimony (MP) analyses (Fig. 1). The tree revealed 14 distinct lineages within the genus, nevertheless the branching order of the lineages in most cases remained unresolved. Five of the lineages belonged to the already known Chlorella species: C. vulgaris, C. lobophora, C. sorokiniana, $C$. heliozoae and $C$. variabilis. The species with colonial life-form and surrounding mucilage envelope evolved at five different positions within the genus Chlorella. Chlorella pituita sp. nov. clustered as sister to $C$. vulgaris with high statistical support in all analyses. The three strains of $C$. pulchelloides sp. nov. clustered next to C. chlorelloides comb. nov. with high to moderate support. Next to this lineage evolved $C$. coloniales sp. nov. and C. singularis (single celled with surrounding mucilage) with no support in any analyses. The relationship of $C$. elongata comb. nov. to the others is also not supported in the analyses. Next to this species evolved the single celled $C$. volutis (without mucilage). $C$. lewinii evolved as sister to $C$. sorokiniana, and $C$. rotunda as sister to $C$. heliozoae with high support in the analyses.

\section{Barcoding and secondary structure analyses}

We investigated the Barcoding region of 49 Chlorella-sequences (published and new sequences; see Table 2) according to MonIz \& KACMARSKA (2009). Interspecific uncorrected genetic distances $(p)$ between strains belonging to the same species ranged from $p=0$ to $p=0.0098$ diff./site (Table 4). Distances among the five species previously thought to be the only species in the genus Chlorella: C. vulgaris, C. sorokiniana, C. lobophora, C. variabilis, C. heliozoae, ranged from $\mathrm{p}=0.0777$ to $p=0.1542$ diff./site. All the 14 species described in this study together showed 


\begin{tabular}{|c|c|c|c|c|c|c|c|c|c|c|c|c|c|c|}
\hline 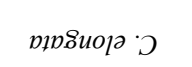 & $\bar{\infty}$ & $\stackrel{0}{m}$ & $\stackrel{n}{m}$ & $\stackrel{4}{1}$ & $\stackrel{0}{m}$ & $\stackrel{0}{m}$ & $\stackrel{t}{m}$ & $\stackrel{0}{m}$ & $\stackrel{4}{4}$ & $\stackrel{m}{n}$ & $\frac{8}{2}$ & $\stackrel{m}{=}$ & $\stackrel{n}{f}$ & \\
\hline symmox : & in & $\stackrel{0}{0}$ & $\frac{m}{n}$ & $\stackrel{m}{R}$ & $\Sigma$ & $\bar{m}$ & ลิ & $\hat{6}$ & $\bar{m}$ & $\vec{\gamma}$ & $\stackrel{f}{a}$ & $\frac{2}{n}$ & & $\stackrel{2}{\varrho}$ \\
\hline salpinolos : & F & $\stackrel{m}{f}$ & $\frac{N}{m}$ & $\stackrel{m}{i}$ & $\stackrel{4}{7}$ & 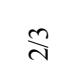 & $\mathrm{N}$ & $\frac{d}{4}$ & F & $\frac{4}{4}$ & $\frac{N}{m}$ & & $\stackrel{\vec{n}}{\stackrel{0}{0}}$ & $\stackrel{\infty}{=}$ \\
\hline 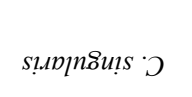 & $\stackrel{m}{n}$ & $\stackrel{+}{*}$ & $\stackrel{n}{m}$ & $\stackrel{4}{a}$ & $\stackrel{m}{m}$ & $\stackrel{+}{\partial}$ & $\frac{1}{n}$ & $\stackrel{ \pm}{R}$ & $\stackrel{A}{a}$ & $\stackrel{m}{=}$ & & $\stackrel{\infty}{\stackrel{\infty}{1}}$ & $\begin{array}{l}\stackrel{0}{0} \\
\stackrel{\infty}{0} \\
0 \\
0\end{array}$ & $\stackrel{\overrightarrow{0}}{0}$ \\
\hline 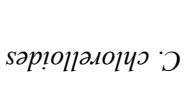 & $\overleftarrow{t}$ & $\frac{m}{m}$ & $\stackrel{m}{i}$ & $\frac{4}{2}$ & $\frac{4}{2}$ & $\stackrel{\Re}{F}$ & $\bar{\lambda}$ & $\stackrel{m}{m}$ & $\stackrel{m}{a}$ & & $\begin{array}{l}\Omega \\
\hat{o} \\
0\end{array}$ & $\frac{\widetilde{\sigma}}{0}$ & $\begin{array}{l}\infty \\
0 \\
0 \\
0\end{array}$ & $\begin{array}{l}\overrightarrow{0} \\
\dot{0}\end{array}$ \\
\hline 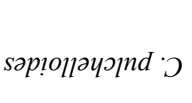 & Sิ & $n$ & $\stackrel{t}{m}$ & S & $\stackrel{4}{n}$ & $\stackrel{m}{=}$ & $\bar{\lambda}$ & $\stackrel{\mathrm{s}}{\mathrm{m}}$ & \% & 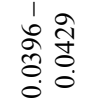 & $\frac{\tilde{o}}{0}, \frac{\hat{g}}{0}$ & $\underset{\Xi}{\Xi}$ & $\begin{array}{l}1 \\
\dot{1} \\
0 \\
0 \\
0 \\
0 \\
0 \\
0 \\
0\end{array}$ & $\begin{array}{l}1 \\
0 \\
0 \\
0 \\
0 \\
0 \\
0 \\
0\end{array}$ \\
\hline 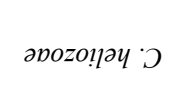 & $\stackrel{N}{m}$ & $\stackrel{m}{m}$ & $\frac{m}{n}$ & $\stackrel{n}{i}$ & $\bar{\lambda}$ & $\stackrel{m}{m}$ & $\frac{4}{2}$ & & 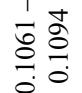 & $\begin{array}{l}\stackrel{1}{1} \\
\stackrel{0}{0} \\
0\end{array}$ & $\underset{0}{\overrightarrow{5}}$ & $\begin{array}{l}\infty \\
\stackrel{\infty}{+\infty} \\
\stackrel{0}{0}\end{array}$ & $\frac{1}{0}$ & $\stackrel{\infty}{\stackrel{\infty}{0}}$ \\
\hline ppumpos & $\bar{\gamma}$ & $\frac{4}{2}$ & $\bar{\lambda}$ & $\bar{m}$ & $\stackrel{?}{=}$ & $\rho$ & & $\begin{array}{l}\overrightarrow{\widetilde{d}} \\
\stackrel{0}{0}\end{array}$ & 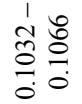 & 命 & $\frac{9}{9}$ & 触 & $\underset{\Xi}{\Xi}$ & $\begin{array}{l}\vec{\infty} \\
\stackrel{0}{0}\end{array}$ \\
\hline & $\frac{m}{a}$ & $\stackrel{0}{m}$ & $\frac{m}{m}$ & $\stackrel{f}{2}$ & 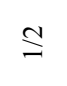 & & $\frac{\text { Oे }}{\stackrel{0}{0}}$ & $\stackrel{\infty}{0}$ & $\begin{array}{l}1 \\
\text { 유 } \\
0 \\
0 \\
0\end{array}$ & $\begin{array}{l}\widehat{\hat{I}} \\
\stackrel{0}{0} \\
0\end{array}$ & $\begin{array}{l}\frac{n}{0} \\
0 \\
0\end{array}$ & $\begin{array}{l}\stackrel{0}{0} \\
\stackrel{0}{0}\end{array}$ & $\begin{array}{l}0 \\
\stackrel{0}{0} \\
0 \\
0\end{array}$ & $\stackrel{\infty}{\stackrel{0}{0}}$ \\
\hline & in & $\stackrel{4}{a}$ & $m$ & $\stackrel{\circ}{m}$ & & है & $\stackrel{0}{0}$ & $\begin{array}{l}\frac{9}{2} \\
5 \\
0\end{array}$ & 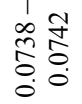 & $\begin{array}{l}0 \\
\text { o. } \\
0 \\
0\end{array}$ & $\begin{array}{l}\infty \\
\stackrel{\mathbb{N}}{0} \\
0 \\
0\end{array}$ & $\begin{array}{l}\stackrel{ \pm}{0} \\
\stackrel{0}{0} \\
0 \\
0\end{array}$ & $\begin{array}{l}\frac{n}{9} \\
\stackrel{5}{0} \\
0\end{array}$ & $\begin{array}{l}\text { I } \\
\text { I } \\
0.0\end{array}$ \\
\hline 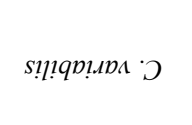 & 子 & in & $\frac{n}{n}$ & & $\begin{array}{l}1 \\
5 \\
0 \\
0 \\
0\end{array}$ & & $\begin{array}{l}1 \\
0 \\
0 \\
0 \\
0 \\
0 \\
0 \\
0\end{array}$ & 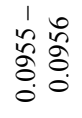 & $\begin{array}{ll} & \infty \\
\circ & 0 \\
0 & 0 \\
0 & 0 \\
0 & 0 \\
0 & 1\end{array}$ & $\begin{array}{l}1 \\
1 \\
8 \\
8 \\
0 \\
0\end{array}$ & $\begin{array}{l}\infty \\
\infty \\
\infty \\
0 \\
0 \\
0\end{array}$ & $\stackrel{\substack{+ \\
\hdashline}}{0}$ & $\begin{array}{l}1 \\
0 \\
0 \\
0 \\
0 \\
0 \\
0\end{array}$ & ڤ్ \\
\hline & in & in & & $\begin{array}{l}0 \\
0 \\
0 \\
0 \\
0\end{array}$ & $\stackrel{\sigma}{\circ}$ & $\frac{\text { in }}{3}$ & $\frac{n}{m}$ & $\stackrel{\Xi}{\Xi}$ & $\begin{array}{l}\text { तo } \\
\text { o. } \\
0 \\
0 \\
0\end{array}$ & $\begin{array}{l}\hat{0} \\
\stackrel{0}{0} \\
0\end{array}$ & $\stackrel{\infty}{\stackrel{\infty}{0}}$ & $\stackrel{\widetilde{N}}{\stackrel{0}{0}}$ & $\frac{\overrightarrow{2}}{0}$ & $\stackrel{\widetilde{N}}{\stackrel{0}{0}}$ \\
\hline 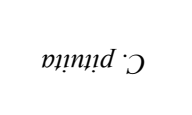 & $\frac{4}{4}$ & & 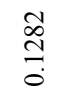 & 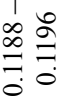 & $\begin{array}{l}\stackrel{0}{\overparen{1}} \\
0\end{array}$ & $\frac{9}{8}$ & $\stackrel{\infty}{\stackrel{\infty}{0}}$ & 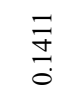 & 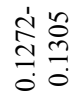 & $\stackrel{0}{\stackrel{0}{0}}$ & $\begin{array}{l}\mathbb{0} \\
\stackrel{0}{0} \\
0\end{array}$ & $\underset{+}{\stackrel{F}{5}}$ & $\frac{0}{n}$ & 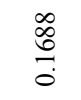 \\
\hline 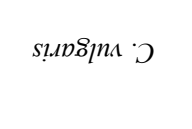 & & $\begin{array}{ll}1 & 0 \\
& 0 \\
0 & 0 \\
0 & 0 \\
0 & 0 \\
0\end{array}$ & 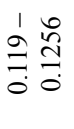 & $\begin{array}{l}1 \\
\stackrel{1}{0} \\
\stackrel{2}{7} \\
0 \\
0\end{array}$ & 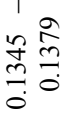 & $\frac{\substack{\mid \\
\frac{9}{ \pm}}}{0} \frac{\sqrt{n}}{0}$ & 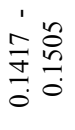 & 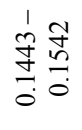 & 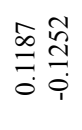 & 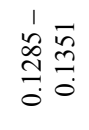 & 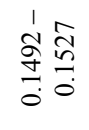 & 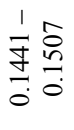 & 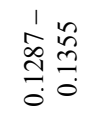 & 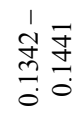 \\
\hline 它兽 & 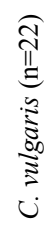 & 栉 & 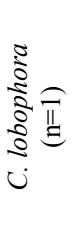 & 离 & 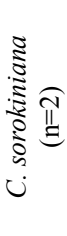 & 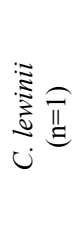 & 离 & 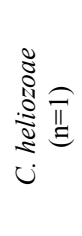 & 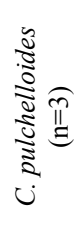 & 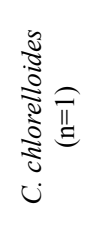 & 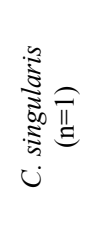 & 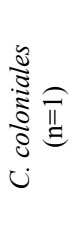 & 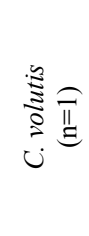 & 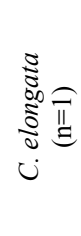 \\
\hline
\end{tabular}


a distance of between $p=0.073$ and $p=0.1741$ diff./site. To confirm the effectiveness of the barcoding region, we calculated the secondary structure of the ITS-2 from these strains and compared all 14 species with each other. We found that the species of the genus Chlorella differ in 1-9 CBCs in the Helices I-III and 0-6 hemi-CBCs respectively. An assumed threshold of $p \geq 0.04$ for species delineation in Chlorella corresponded well with the $\mathrm{CBCs}$ and hemi-CBCs of the helixes I-III of the ITS-2 (see Table 4). A low $p$ value was correlated with a low $\mathrm{CBC} / \mathrm{hemi}-\mathrm{CBC}$ content.

\section{Discussion}

The focus of this study was to revise the species concept of Chlorella. We provided an emendation of the genus including taxa which form mucilaginous envelopes and colonies. This systematic revision was made possible by use of molecular signatures. We tested the barcoding concept as described by Moniz \& KACZMARSKA (2009) in regard to members of the genus Chlorella. The concept was developed for diatoms and successfully tested for Mediophyceae and Bacillariophyceae and had a success rate of $99.9 \%$ in separating biologically defined species (MonIZ $\&$ KACZMARSKA 2009). The ITS is widely used for phylogenetic studies of different organisms and is under consideration as barcode region in several cases. LITAKER et al. (2007) suggested using this region as barcode for dinoflagellates, and SEIFERT (2009) applied it as barcode for fungi. Coleman (2009) pointed out that variation in this DNA region correlates with taxonomic classification. So far, there is no official code for green algae. However, $\mathrm{CBCs}$ in the ITS have been used in many taxonomic studies and have proven to be powerful tools for species separation (KRIENITZ et al. 2004, 2010; MüLler et al. 2007; Wolf et al. 2007; RuHL et al. 2009). As our study showed, the 5.8S and ITS-2 region works well for Chlorella as a tool for species delineation. The separation according the barcode region correlates with the $\mathrm{CBCs}$ and hemi-CBCs in the region.

The species delineation in Chlorella has always been a problem because the morphological characters separating individual species are scarce and not easy to observe. In applying the barcoding regions, we were able to separate the already known "true" Chlorella species: C. vulgaris, C. lobophora, C. variabilis, C. heliozoae and
C. sorokiniana without problems. In addition, two formerly Dictyosphaerium species, $D$. chlorelloides and D. elongatum showed a close phylogenetic relationship to Chlorella and were therefore transferred to the genus Chlorella (see above). Although the original species description of $D$. chlorelloides mentions a cell size of 3.8$6(-7.5) \mu \mathrm{m}$, which is slightly smaller than strain CCAP 211/116 cells $(6.2-8.4 \mu \mathrm{m})$, all other characters matched to the latter. Given that there was no authentic strain available for this species, and that cell size is often dependent on culture conditions and life cycle, we decided to transfer the species Dictyosphaerium chlorelloides to Chlorella. In addition to this, we described three new species with colonial life-form and gelatinous envelope. Chlorella pituita, C. pulchelloides and C. colonialis showed the typical morphology of the genus Dictyosphaerium, but had no similarities to the already known species. The type strain of $C$. pituita was labelled as D. tetrachotomum in the ACOI collection. Although the description of this species mentions oval cells, the strains showed spherical cells. The strain ACOI 856, which revealed the same sequence as the type strain exhibited as single celled morphology with a gelatinous indusium. A similar problem arose with the strain UTEX 938. The strain was initially labelled as $D$. planctonicum TIFF. et AhLsTR., this was later transferred to Lobocystis R.H. Thомpson and was characterized by two autospores and broad gelatinous stalks (KOMÁREK $\&$ Fотт 1983). These characters did not match the morphology of UTEX 938, and we erected the new species $C$. coloniales. The strain SAG 222-2a was often referred as D. pulchellum. Our observations showed considerable differences in the morphology of the young cells. Strains with the $D$. pulchellum morphology cluster next to $D$. ehrenbergianum within the Parachlorella-clade (Bock et al. in press). Therefore, the new lineage with the strains SAG 222-2a, CCAP 211/117 and CCAP 211/118 formed a new species, $C$. pulchelloides even if they bear a high similarity with $D$. pulchellum.

The independent evolution of Dictyosphaerium morphotype in different clades of the Chlorellaceae has been discussed by BocK et al. (2010) and Krienitz et al. (2010). Our analyses confirmed the independent evolution of Dictyosphaerium in different clades of the Chlorellaceae and revealed a major change in the understanding of typical Chlorella species. Instead 
of the more or less uniform "green balls", several members with different morphologies now occur in Chlorella s. str. The type species Chlorella vulgaris was considered as the typical Chlorella: small, green and more or less spherical. Our analyses showed that the generic circumscription was way too narrow and is now emended (see above). The question that is raised by these findings is the extent to which morphology is influenced by the environment.

The investment of phytoplankton in mucilage is a striking feature in nature. The presence or absence of mucilage is in most cases taxon specific, but the thickness is variable and often influenced by environmental factors (REYNOLDS 2007). Biological investigations on the role of the mucilage coat suggest that there is no single, unambiguous function of mucilage. Often discussed is the role played by the mucilage indusium and the colony size of algae in grazing protection and the factors that influence its size and thickness. A common assumption is that large phytoplankton cannot be grazed due to size mismatch. Several studies on the colonial and gelatinous algae Phaeocystis (Prymnesiophyceae) revealed an increase in colony-size as a result of chemicals released from grazer or associated microbes (JAKOBSON \& TANG 2002; TANG et al. 2008). Another example is the well-studied chlorophyte genus Scenedesmus Meyen. Biotests with Scenedesmus in culture revealed an increase in the colony-size due to "Daphnia-factors" (Hessen \& van Donk 1993; LAMPERT et al. 1994; LÜRLING 1998; von ElERT \& FrANK 1999; WiltShire \& LAMPERT 1999) as well as "Brachionus-factors" (VERSCHOOR et al. 2004). Another example of an environmentally induced morphological change is the bristle formation by Micractinium, a close relative of Chlorella, which has been linked to the "Brachionus-factors" (LuO et al. 2006). Nevertheless, factors responsible for the appearance of the Dictyosphaeriummorphotype are yet to be resolved. As to whether or not the mucilage production is a response to environmental factors remains to be confirmed.

\section{Acknowledgements}

This research was financially supported by the Deutsche Forschungsgemeinschaft (KR 1262/11-1, 2) and NERC Oceans 2025 and NERC MGF 154 sequencing grant. Eberto Novelo provided a strain of Chlorella pulchelloides from Mexico. We thank M. Degebrodt and M. Papke for technical assistance and Kiplagat Kotut for helpful discussions on early draft of this article.

\section{References}

Alvarez, I. \& Wendel, J. F. (2003): Ribosomal ITS sequences and plant phylogenetic inference. Mol.Phylogenet.Evol. 29: 417-434.

Andreyeva, V.M. (1975): Rod Chlorella: Morfologya, Sistematika, Prinzipy Klassifikaziyi. -88 pp., Nauka, Leningrad.

Atkinson, A.W., John, P.C.L. \& Gunning, B.E.S. (1972): Sporopollenin in the cell-wall of Chlorella and other Algae: ultrastructure, chemistry, and incorporation of ${ }^{14} \mathrm{C}$-acetate, studied in synchronous cultures. - Planta 107: $1-32$.

Bock, C., Pröschold, T. \& Krienitz L. (2010): Two new phylogenetic lineages of Dictyosphaerium morphotype within Chlorellaceae (Trebouxiophyceae): Heynigia gen. nov. and Hindakia gen. nov. - Eur.J.Phycol. 45: 267277.

Bock, C., Pröschold, T. \& Krienitz L. (in press): Updating the genus Dictyosphaerium and description of Mucidosphaerium gen. nov. (Trebouxiophyceae) based on morphological and molecular data. - J.Phycol.

Coleman, A.W. (2007): Pan-eukaryote ITS2 homologies revealed by RNA secondary structure. - Nucl.Acids Res. 35: 3322-3329.

Coleman, A.W. (2009): Is there a molecular key to the level of "biological species" in eukaryotes? A DNA guide. - Mol.Phylogenet.Evol.50: 197203.

Comas, A. (1992): Taxonomical contributions to the green algal flora (Chlorellales) of Cuba. - Arch. Hydrobiol. 93/Algological Studies 65: 11-21.

Darienko, T., Gustavs, L., Mudimu, O., Rad Menendez, C., Schumann, R., Karsten, U., Friedl, T. \& PRÖschold, T. (2010): Chloroidium, a common terrestrial coccoid green alga previously assigned to Chlorella (Trebouxiophyceae, Chlorophyta). - Eur.J.Phycol. 45: 79-95.

Eliaš, M. \& Neustupa, J. (2009): Pseudomarvania, gen. nov. (Chlorophyta, Trebouxiophyceae), a new genus for "budding" subaerial green algae Marvania aerophytica Neustupa et Šejnohová and Stichococcus ampulliformis Handa. - Fottea 9: 169-177.

Ettl, H. \& GÄRTnER, G. (1995): Syllabus der Boden-, Luft- und Flechtenalgen. - 729 pp. Gustav Fischer, Jena, New York.

Evans, K.M., Wortley, A.H. \& Mann, D.G. (2007): An assessment of potential diatom "barcode" genes (cox1, rbcL, 18S and ITS rDNA) and their effectiveness in determining relationships in Sellaphora (Bacillariophyta). - Protist 158: 349-364.

Evans, K.M. \& Mann, D.G. (2009): A proposed protocol for nomenclaturally effective DNA 
barcoding of microalgae. - Phycologia 48: $70-74$.

Fotт, B. \& NovÁkovÁ, M. (1969): A monograph of the genus Chlorella. The freshwater species. In: Fotт, B. (ed.): Studies in Phycology. - pp. 10-74, Academia, Prague.

Gemeinholzer, B., Droege, G., Zetsche, H., Knebelsberger, T., Raupach, M., Borsch, T., Klenk, H.-P., Haszrpunar, G. \& Waegele, J.-W. (2009): DNA Bank Network Webportal.

Hajibabaei, M., Singer, G.A. C., Hebert, P.D.N. \& HickeY, D.A. (2007): DNA barcoding: how it complements taxonomy, molecular phylogenetics and population genetics. - Trends in Genetics 23: 167-172.

Hepperle, D. SequentiX Alignment Editor. (2004): Distributed by Author.

Hessen, D.O. \& van Donk, E. (1993): Morphological changes in Scenedesmus induced by substances released from Daphnia. - Arch Hydrobiol. 127: 129-140.

Hoshina, R., Kato, Y., Kamako, S. \& Imamura, N. (2005): Genetic evidence of "American" and "European" type symbiotic algae of Paramecium bursaria Ehrenberg. - Plant Biol. 7: 526-532.

HuElsenBeCK, J.P. \& RonQuist, F. (2001): MRBAYES: Bayesian inference of phylogenetic trees. Bioinformatics 17: 754-755.

Huss, V.A.R., Scharpf, T.K. \& Kessler, E. (1989): Deoxyribonucleic-Acid reassociation in the taxonomy of the genus Chlorella - Chlorella vulgaris, C. luteoviridis, C. minutissima, and Chlorella zofingiensis. - Arch.Microbiol. 152: 512-514.

Huss, V.A.R. \& Sogin, M.L. (1990): Phylogenetic position of some Chlorella species within the Chlorococcales based upon complete smallsubunit ribosomal-RNA sequences. - J.Mol. Evol. 31: 432-442.

Huss, V.A.R., Frank, C., Hartmann, E.C., Hirmer, M., Kloboucek, A., Seidel, B. M., Wenzeler, P. \& KESSLER, E. (1999): Biochemical taxonomy and molecular phylogeny of the genus Chlorella sensu lato (Chlorophyta). - J.Phycol. 35: 587598.

IKedA, T. \& TAKedA, H. (1995): Species-specific differences of pyrenoids in Chlorella (Chlorophyta). - J. Phycol. 31: 813-818.

JoвB, G. TREEFINDER version of October 2008. Munich, Germany. Distributed by the author at www.treefinder.de.

JAKOBSEN, H.H. \& TANG, K.W. (2002): Effects of protozoan grazing on colony formation in Phaeocystis globosa (Prymnesiophyceae) and the potential costs and benefits. - Aquat.Microb. Ecol. 27: 261-273.

KAPAUN, E. \& REISSER, W. (1995): A chitin-like glycan in the cell-wall of a Chlorella sp. (Chlorococcales,
Chlorophyceae). - Planta 197: 577-582.

Kessler, E. (1976): Comparative physiology, biochemistry, and taxonomy of Chlorella (Chlorophyceae). - Plant.Syst.Evol. 125: 129138.

Kessler, E. (1982): Chemotaxonomy in the Chlorococcales. - In: Round, F.E. \& CHAPMAN, D.J. (eds): Progress in Phycologica Research. - pp. 111-135, Elsevier Biomedical - NorthHolland.

KESSLER, E.(1984): Ageneral review on the contributions of chemotaxonomy to the systematics of green algae. - In: IRvine, D.E.G. \& JoHn, D.M. (eds.): Systematics of the Green Algae. - pp. 391-407, Academic Press, London.

Kessler, E. \& Huss, V.A.R. (1992): Comparative physiology and biochemistry and taxonomic assignment of the Chlorella (Chlorophyceae) strains of the culture collection of the University of Texas at Austin. - J.Phycol. 28: 550-553.

Khaybullina, L.S., Gaysina, L.A., Johansen, J.R. \& KrautovÁ, M. (2010): Examination of the terrestrial algae of the Great Smoky Mountains National Park, USA. - Fottea 10: 201-215.

KomáreK, J. \& Fott, B. (1983): Chlorophyceae (Grünalgen) Ordnung: Chlorococcales. - In: Huber-Pestalozzi, G. (ed.): Das Phytoplankton des Süßwassers 7. Teil, 1. Hälfte. - 1044 pp., E. Schweizerbart'sche Verlagsbuchhandlung (Nägele u. Obermiller) - Stuttgart.

Komárek, J. \& Perman, J. (1978): Review of the genus Dictyosphaerium (Chlorococcales). - Arch. Hydrobiol. 51/Algological Studies 20: 233297.

Krienitz, L., Bock, C., LuO, W. \& Pröschold, T. (2010): Polyphyletic origin of the Dictyosphaeriummorphotype within Chlorellaceae (Trebouxiophyceae). - J.Phycol. 46: 559-563.

Krienitz, L., Hegewald, E. H., Hepperle, D., Huss, V.A.R., Rohr, T. \& Wolf, M. (2004): Phylogenetic relationship of Chlorella and Parachlorella gen. nov. (Chlorophyta, Trebouxiophyceae). - Phycologia 43: 529-542.

Krienitz, L., Hegewald, E., Hepperle, D. \& Wolf, M. (2003): The systematics of coccoid green algae: 18S rRNA gene sequence data versus morphology. - Biologia 58: 437-446.

KrienitZ, L. \& WiRTh, M. (2006): The high content of polyunsaturated fatty acids in Nannochloropsis limnetica (Eustigmatophyceae) and its implication for food web interactions, freshwater aquaculture and biotechnology. - Limnologica 36: 204-210.

LAMPert, W., RothHaupt, K.O. \& von Elert, E. (1994): Chemical induction of colony formation in a green alga (Scenedesmus acutus) by grazers (Daphnia). - Limnol.Oceanogr. 39: 15431550 . 
Litaker, R.W., Vandersea, M.W., Kibler, S.R., Reece, K.S., Stokes, N.A., Lutzoni, F.M., Yonish, B.A., West, M.A., Black, M.N.D. \& Tester, P.A. (2007): Recognizing dinoflagellate species using ITS rDNA sequences. - J.Phycol. 43: 344-355.

Luo, W., Pflugmacher, S., Pröschold, T., Walz, N. \& KRIENITZ, L. (2006): Genotyp versus phenotype variability in Chlorella and Micractinium (Chlorophyta, Trebouxiophyceae). - Protist 157: 315-333.

Luo, W., Pröschold, T., Bock, C. \& Krienitz, L. (2010): Generic concept in Chlorella-related coccoid green algae (Chlorophyta, Trebouxiophyceae). - Plant Biol. 12: 545-553.

LÜRLING, M. (1998): Effect of grazing-associated infochemicals on growth and morphological development in Scenedesmus acutus (Chlorophyceae). - J.Phycol. 34: 578-586.

Miao, M., Warren, A., Song, W.B., Wang, S., Shang, H.M. \& Chen, Z. G. (2008): Analysis of the internal transcribed spacer 2 (ITS2) region of scuticociliates and related taxa (Ciliophora, Oligohymenophorea) to infer their evolution and phylogeny. - Protist 159: 519-533.

Moniz, M.B.J. \& KaczmarsKa, I. (2009): Barcoding diatoms: Is there a good marker? - Mol.Ecol. Resour. 9: 65-74.

Müller, T., Philippi, N., Dandekar, T., Schultz, J. \& Wolf, M. (2007): Distinguishing species. RNA 13: 1469-1472.

NĚmcová, Y. \& Kalina, T. (2000): Cell wall development, microfibril and pyrenoid structure in type strains of Chlorella vulgaris, C. kessleri, C. sorokiniana compared with $C$. luteoviridis (Trebouxiophyceae, Chlorophyta). - Algological Studies 100: 95-105.

Neustupa, J., NĚmcová, Y., Eliaš, M. \& Škaloud, P. (2009): Kalinella bambusicola gen. et sp. nov. (Trebouxiophyceae, Chlorophyta), a novel coccoid Chlorella-like subaerial alga from Southeast Asia. - Phycol.Res. 57: 159-169.

Nishihara, N., Horime, S., Takahashi, T., Kosaka, T., Shigenaka, Y. \& Hosoya, H. (1998): Cloning and characterization of endosymbiotic algae isolated from Paramecium bursuria. Protoplasma 203: 91-99.

Nozaki, H., Katagiri, M., Nakagawa, M., Aizawa, K. \& Watanabe, M.M. (1995): Taxonomic reexamination of two strains labeled 'Chlorella' in the microbial culture collection at the National Institute for Environmental Studies (NIESCollection). - Microbial Culture Collections 11: $11-18$.

Pröschold, T. \& Leliaert, F. (2007): Systematics of the green algae: conflict of classic and modern approaches. - In: BRodie, J. \& Lewis, J.M. (eds): Unravelling the algae: the past, present, and future of algal systematics. - pp. 123-153, CRC Press - Boca Raton, FL (USA).

Pröschold, T., Darienko, T., Silva, P.C., Reisser, W. \& Krienitz, L. (2011): The systematics of "Zoochlorella" revisited employing an integrative approach. - Environ.Microbiol.: 13: $350-364$.

REYNOLDS, C.S. (2007): Variability in the provision and function of mucilage in phytoplankton: facultative responses to the environment.Hydrobiologia 578: 37-45.

Ruhl, M.W., Wolf, M. \& Jenkins, T.M. (2010): Compensatory base changes illuminate taxonomically difficult taxonomy. - Mol. Phylogen.Evol. 54: 664-669.

Sanders, B.G., Keller, E.C. \& Wiley, K.L. (1971): Identification of Chlorella strains by serological techniques. - J.Phycol. 7: 63-64.

Seibel, P.N., Müller, T., Dandekar, T., Schultz, J. \& Wolf, M. (2006): 4SALE - A tool for synchronous RNA sequence and secondary structure alignment and editing. - BMC Bioinf. 7: 498.

Seibel, P.N., Dandekar, T., Müller, T. \& Wolf, M. (2008): Synchronous visual analysis and editing of RNA sequence and secondary structure alignments using 4SALE. - BMC Res. Notes 91: 1-7.

SeIFERT, K.A. (2009): Progress towards DNA barcoding of fungi. - Mol.Ecol.Res. 9: 83-89.

Shinira, J. \& Krauss, R.W. (1965): Chlorella. Physiology and taxonomy of fourty-one isolates. - 92 pp., University of Maryland, College Park, MD, USA.

Shrift, A. \& Sproul, M. (1963): Sulfur nutrition and the taxonomy of Chlorella. - Phycologia 3: $85-100$.

ŠKaloud, P. (2009): Species composition and diversity of aero-terrestrial algae and cyanobacteria of the Boreč Hill ventaroles. - Fottea 9: 65-80.

Summerer, M., Sonntag, B. \& Sommaruga, R. (2008): Ciliate-symbiont specificity of freshwater endosymbiotic Chlorella (Trebouxiophyceae, Chlorophyta). - J.Phycol. 44: 77-84.

Swofford, D.L. (2002): Phylogenetic analysis using parsimony (* and other methods), PAUP version 4.0b 10. 2003. Massachusetts, Sinauer Associates, Sunderland.

Tang, K.W., Smith, W.O., Elliott, D.T. \& Shields, A.R. (2008): Colony size of Phaeocystis antarctica (Prymnesiophyceae) as influenced by zooplankton grazers. - J.Phycol. 44: 13721378.

Verschoor, A.M., van der Stap, I., Helmsing, N.R., LÜRLING, M. \& VAN DONK, E. (2004): Inducible colony formation within the Scenedesmaceae: Adaptive responses to infochemicals from two different herbivore taxa. - J.Phycol. 40: 808- 
814.

VON Elert, E. \& Franck, A. (1999): Colony formation in Scenedesmus: grazer-mediated release and chemical features of the infochemical. J.Plankton Res. 21: 789-804.

Wiltshire, K.H. \& LAMPert, W. (1999): Urea excretion by Daphnia: A colony-inducing factor in Scenedesmus? - Limnol.Oceanogr. 44: 18941903.

Wolf, M., Selig, U., Müller, T., PhilipPi, N., Dandekar, T. \& Schultz, J. (2007): Placozoa: at least two. - Biologia 62: 641-645.

Zuker, M. (2003): Mfold web server for nucleic acid folding and hybridization prediction. - Nucl. Acids Res. 31: 3406-3415.

(C) Czech Phycological Society (2011)

Received November 24, 2010

Accepted January 19, 2011 